(c) American Dairy Science Association, 2005.

\title{
Automatic Cluster Remover Setting Affects Milk Yield and Machine-On Time in Dairy Cows
}

\author{
A. L. Magliaro and R. S. Kensinger \\ Department of Dairy and Animal Science, \\ The Pennsylvania State University, University Park 16802
}

\begin{abstract}
The primary objectives of this study were to examine effects of automatic cluster remover (ACR) settings on milk yield and machine-on time, and to describe variation in cow body weight (BW) associated with day of bovine somatotropin (bST) cycle. Automatic cluster removal settings of $0.48,0.6$, and $0.8 \mathrm{~kg} / \mathrm{min}$ were used to regulate the end of milk removal. The setting was changed every $2 \mathrm{wk}$ for $12 \mathrm{wk}$ and followed the sequence $0.8,0.6,0.48,0.48,0.6$, and $0.8 \mathrm{~kg} / \mathrm{min}$. Milk yield, machine-on time, and BW were measured for $60 \mathrm{Hol}-$ stein cows at each milking. Milk yield averaged 19.7, 19.9 , and $19.3 \mathrm{~kg} / \mathrm{cow}$ per milking for ACR settings of $0.48,0.6$, and 0.8 , respectively. There was a $2.5 \%$ reduction in milk yield at the high setting, but yields were similar for the others. Machine-on time was 6.3, 5.9 , and $5.6 \mathrm{~min}$ for ACR settings of $0.48,0.6$, and 0.8 , respectively. There was an $11.1 \%$ reduction in milking time between the $0.8-$ and $0.48-\mathrm{kg} / \mathrm{min}$ settings. The middle ACR setting yielded a shorter milking time than the low setting without reducing production. Milk yield and cow BW increased over the 14-d bST cycle, peaking by $\mathrm{d} 8$, and then declining through $\mathrm{d} 14$. Automated collection of milk yield, milking time, and BW at each milking can be used to establish normal patterns for individual animals, which could be useful in making management decisions.
\end{abstract}

(Key words: automatic cluster remover, milk yield, machine-on time, bST)

Abbreviation key: ACR = automatic cluster remover.

\section{INTRODUCTION}

Maximum profitability on commercial dairies requires optimizing milk production and reducing associated costs. Because labor is one of the highest costs for dairy farms, more efficient use of labor could translate into significant savings. A review of earlier advances

Received August 10, 2004

Accepted October 8, 2004.

Corresponding author: Ronald S. Kensinger; e-mail: rsk7@psu.edu. in milking equipment design and labor use was provided by Thompson (1981). A goal should be to reduce milking time without sacrificing production or animal health. Reduced machine-on time may also decrease the incidence or severity of teat-end lesions (Neijenhuis et al., 2000) and potentially reduce the occurrence of mastitis (Neijenhuis et al., 2001). Individual cow milk production, milking machine idle time, and milking time are important factors that affect parlor efficiency. The first description of automatic milking machine removal was by Armstrong et al. (1970), and the major equipment manufacturers offer this as an option today. The duration of milking can be altered by changing the end-of-milking flow setting for automatic cluster remover (ACR). There are few reports on the effect of ACR settings on milk yield and milking time in the scientific literature. Thus, the optimum flow rate setting for end of milking is not known. Historically, cows were considered milked out when the milk flow rate decreased to $0.2 \mathrm{~kg} / \mathrm{min}$, and commercially available automatic cluster removers were often set near that arbitrary threshold (Sagi, 1978).

Sagi (1978) and Rasmussen (1993) conducted studies to compare ACR settings corresponding to milk flow rates of 0.2 and $0.4 \mathrm{~kg} / \mathrm{min}$. Sagi (1978) observed that milk production was similar between ACR settings. However, daily milking time was significantly faster for cows milked with the $0.4-\mathrm{kg} / \mathrm{min}$ setting. Rasmussen (1993) reported similar results showing a significant reduction in machine-on time at the higher ACR setting with no change in milk yield. Stewart et al. (2002) conducted a field trial using ACR settings between 0.5 and $0.82 \mathrm{~kg} / \mathrm{min}$ in 5 commercial dairy herds. At the higher settings, average milking duration per cow decreased, but milk yield results were variable.

Touchberry and Markos (1970) concluded that within the same breed, cow accounted for $55.7 \%$ of the total variance in milking time. Thomas et al. (1993) reported that individual animal accounted for $44.3 \%$ of the variance in milk flow time for Holstein cows. Therefore, it is important to quantify effects of ACR setting on milk production and milking time for individual cows to assess the effects of different milking parlor settings for milking machine removal. In the past it was difficult 
to collect these data on a large number of animals for any length of time due to constraints of technology and labor. Sagi (1978) used only 16 cows over $21 \mathrm{~d}$. Rasmussen (1993) used 135 cows, but measured milk yield and milking time at only 2 milkings per week. Stewart et al. (2002) conducted a 5-herd field trial (average $728 \pm$ 308 cows/herd), with cows entering and leaving the herd during the study.

The AFIfarm system (S.A.E. Afikim, Kibbutz AFIKIM, Israel) allows dairies to record milk production and milking time for individual cows at each milking. Although many modern milking parlors are installed with default ACR settings below $0.5 \mathrm{~kg} / \mathrm{min}$, some producers use higher settings to reduce milking time (Reid and Stewart, 1997). Our objectives were to use the AFIfarm system to examine the effects of 3 ACR settings on individual milk production and milking time in healthy, high-producing dairy cows. A second objective was to compare the responses of first-lactation cows with those of multiparous cows. A third objective was to describe variation in BW and milk yield associated with the 14-d bST treatment cycle, as this is useful information for dairy herd management (Maltz, 1997; Østergaard and Gröhn, 1999).

\section{MATERIALS AND METHODS}

Sixty Holstein cows in lactation 1 to 6 were used. Cows averaged $162 \pm 51 \mathrm{~d}$ in milk and $644 \pm 100 \mathrm{~kg}$ BW at the onset of the study, and each was available for the duration of the 12-wk experiment. All cows were beyond 60 DIM at the beginning of the study. Cows were milked twice a day at 0500 and $1700 \mathrm{~h}$ in a double10 herringbone milking parlor equipped with the Afifarm system (S.A.E. Afikim, Kibbutz Afikim, Israel; US distributor: Germania Dairy Automation, Waunakee, WI). They were predipped with an iodine-based teat dip, forestripped, and dried with individual towels. There was a 50-s interval from forestripping until unit attachment. Reattachment of milking units to cows was discouraged, and occurred in less than $2 \%$ of milkings during the study. Milk yield and milking time were recorded for individual animals at each milking, and cows were weighed upon exiting the parlor.

The AFIfarm F2 delay time settings were changed at 2 -wk intervals during the 12 -wk experiment. This system uses a milk meter body that holds $200 \mathrm{~mL}$ of milk. When the meter is full, an electrode is activated, and the meter is emptied. Machine removal is based on how long it takes to fill the milk meter body. We used delay time settings of 15,20 , and $25 \mathrm{~s}$, which corresponded to ACR settings of $0.8,0.6$, and $0.48 \mathrm{~kg}$ of milk/min, respectively, at machine removal. The sequence of ACR settings for the 2 -wk periods was 0.8 ,
$0.6,0.48,0.48,0.6,0.8 \mathrm{~kg} / \mathrm{min}$ to balance results for variation in DIM. AFIfarm setting F1, the minimum milking time intended to prevent premature removal of the milking machine, was maintained at $3 \mathrm{~min}$. Setting F3, the amount of time from the end of milking as determined by the F2 setting to the actual removal of the unit, was set at $1 \mathrm{~s}$. Vacuum level was $45.4 \mathrm{kPa}$, pulsation ratio was 65:35, and pulsation rate was 60 pulsations/min. Before and after the experiment, an independent dealer used flowmeters to verify that equipment settings worked properly.

Cows were from the university dairy herd and had ad libitum access to a TMR designed to meet nutrient requirements based on level of milk production. All animals received biweekly bST injections on $\mathrm{d} 1$ of each 2wk experimental period. Periods were $14 \mathrm{~d}$ in length to encompass the bST cycle.

One cow was removed from the study due to prolonged effects of traumatic reticulo peritonitis. Seven cows experienced periods of diarrhea, fever, or mastitis that caused substantial declines in milk yield for 3 to $25 \mathrm{~d}$. Because the primary objective of this experiment was to determine the effects of ACR settings on milk production and milking time in healthy cows, data during these periods of illness were deleted. Less than $0.9 \%$ of data were removed from the analysis for these reasons. The incidence of clinical mastitis in the experimental cows was recorded. The Institutional Animal Care and Use Committee approved procedures.

Data were analyzed using the mixed procedure of SAS (Statistical Analysis System version 8.2, SAS Inst. Inc., Cary, NC; as described in Littell et al., 1996). Parity or age effects were examined in 2 groups: first lactation $(n=24)$ or lactations 2 to $6(n=35)$. The models for milk yield and milking time analyses included ACR setting, day of bST cycle, milking (a.m. or p.m.), parity, and first-order interactions. The model for BW analysis contained parity, period, day of bST cycle, milking (a.m. or p.m.), and first-order interactions. There were six 14-d periods over the 12-wk study. For all analyses, subject was cow (parity), and milking (a.m. or p.m.) $\times$ date was used as the repeated measure with a compound symmetry covariance matrix, which produced the best fit for all variables.

\section{RESULTS}

Mean milk yields per milking were 19.7, 19.9, and $19.3 \mathrm{~kg}$ for the $0.48-, 0.6-$, and $0.8-\mathrm{kg} / \mathrm{min}$ ACR settings, respectively (Figure 1). Milk production at the 0.8-kg/ min setting was slightly lower than that observed with either the $0.48-$ or $0.6-\mathrm{kg} / \mathrm{min}$ settings $(P<0.01$, Table 1 ), but yields were similar for the 0.48 - and $0.6-\mathrm{kg} /$ min settings. 


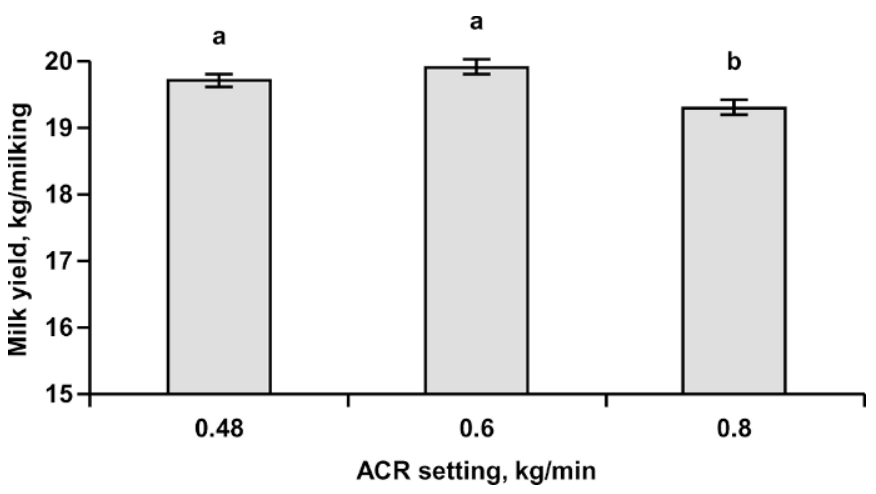

Figure 1. Milk yields of cows milked at 3 automatic cluster remover (ACR) settings. Each bar represents data from 59 cows and over 3200 milkings. All cows received all treatments in a repeated measures design. Bars with different superscripts differ $(P<0.01)$.

Mean milking times per milking were $6.3,5.9$, and $5.6 \mathrm{~min}$ for the $0.48-, 0.6-$, and $0.8-\mathrm{kg} / \mathrm{min}$ ACR settings, respectively (Figure 2). Each was significantly different from the others $(P<0.01$, Table 1$)$.

Milk production and milking time were not affected by parity $(P>0.05)$. First-lactation and older animals averaged 19.1 and $20.0 \mathrm{~kg} / \mathrm{milking}$ and 5.8 and $6.0 \mathrm{~min} /$ milking, respectively (Table 1$)$. Cows produced more $(P$ $<0.01)$ and took longer to milk $(P<0.01)$ at the a.m. vs. p.m. milking (20.3 vs. $18.9 \mathrm{~kg}$; 6.0 vs. 5.9 min., respectively).

Milk yield and BW changed over the course of the bST cycle $(P<0.01$, Tables 1 and 2 , Figure 3$)$. Milk yield and BW increased from $\mathrm{d} 1$ to $\mathrm{d} 7$ and $\mathrm{d} 8$, respectively, and then decreased until d 14. Milk production increased by $1.8 \mathrm{~kg} /$ milking from nadir to peak, whereas BW increased by $11 \mathrm{~kg} / \mathrm{cow}$. In this study, cows showed a rapid response to $\mathrm{bST}$ as evidenced by the significant increase in milk yield on d 1 compared with d 14 of

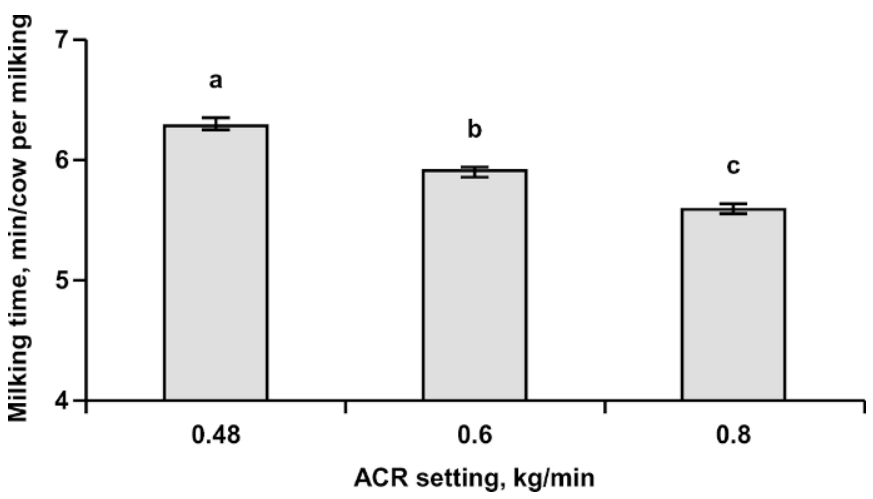

Figure 2. Machine-on times of cows milked at 3 automatic cluster remover (ACR) settings. Each bar represents data from 59 cows and over 3190 milkings. All cows received all treatments in a repeated measures design. Bars with different superscripts differ $(P<0.01)$.

the cycle $(P<0.01)$. Day 1 represented the 2 milkings following bST injection. As expected, older cows weighed more than first-parity animals ( $728 \mathrm{vs.} 586 \mathrm{~kg}$, $P<0.01$, Table 2).

The pattern of milk production across the 14-d bST cycle was similar for all ACR settings in that milk yield increased from $d 1$ to 8 for all settings, with average milk yield slightly higher in the 0.48 - and $0.6-\mathrm{kg} / \mathrm{min}$ settings than for the $0.8-\mathrm{kg} / \mathrm{min}$ setting, and the decline in milk yield from d 8 to 14 was greater when cows were milked with the $0.8-\mathrm{kg} / \mathrm{min}$ setting. Milk yield was higher in the a.m. vs. p.m. for both older and first lactation cows, but the p.m. decline was greater for firstlactation cows than for older cows. For all ACR settings, the pattern of change in milk yield was similar for a.m. and p.m. milkings, but p.m. milk production was lower. Likewise, a.m. milk yields were higher compared with p.m. but the change in production was similar across bST day (data not shown).

Table 1. Statistical analysis of milk yield and machine-on time in cows milked with automatic cluster remover (ACR) settings of $0.48,0.6$, and $0.8 \mathrm{~kg}$ milk $/ \mathrm{min}$.

\begin{tabular}{|c|c|c|c|c|c|c|}
\hline \multirow[b]{2}{*}{ Effect } & \multicolumn{3}{|c|}{ Milk yield } & \multicolumn{3}{|c|}{ Machine-on time } \\
\hline & Num. ${ }^{1} \mathrm{df}$ & Denom. ${ }^{2} \mathrm{df}$ & $F$ value & Num. df & Denom. df & $F$ value \\
\hline ACR setting & 2 & 9550 & $44.3^{* *}$ & 2 & 9553 & $396.1 * *$ \\
\hline bST day & 13 & 9550 & $27.7 * *$ & 13 & 9553 & $8.1^{* *}$ \\
\hline Milking (a.m. or p.m.) & 1 & 9550 & $835.4^{* *}$ & 1 & 9553 & $50.9^{* *}$ \\
\hline Parity & 1 & 57 & 0.7 & 1 & 57 & 0.3 \\
\hline ACR setting $\times$ bST day & 26 & 9550 & $4.0 * *$ & 26 & 9553 & 1.5 \\
\hline ACR setting $\times$ milking & 2 & 9550 & $4.2^{*}$ & 2 & 9553 & 0.3 \\
\hline ACR setting $\times$ parity & 2 & 9550 & 1.2 & 2 & 9553 & $9.4^{* *}$ \\
\hline Milking $\times$ bST day & 13 & 9550 & $2.8^{* *}$ & 13 & 9553 & $2.0^{*}$ \\
\hline Parity $\times$ bST day & 13 & 9550 & 1.0 & 13 & 9553 & 0.7 \\
\hline Parity $\times$ Milking & 1 & 9550 & $45.9^{* *}$ & 1 & 9553 & 0.1 \\
\hline
\end{tabular}

\footnotetext{
${ }^{1}$ Numerator.

${ }^{2}$ Denominator.

${ }^{*} P<0.05$, ${ }^{* *} P<0.01$.
} 
Table 2. Statistical analysis of body weight in cows weighed twice daily.

\begin{tabular}{lccc}
\hline Effect & Num. ${ }^{1} \mathrm{df}$ & Denom. $^{2} \mathrm{df}$ & $F$ value \\
\hline Parity & 1 & 57.3 & $115.5^{* *}$ \\
Period & 5 & 7623 & $531.7^{* *}$ \\
bST day & 13 & 7623 & $18.0^{* *}$ \\
Milking (a.m. or p.m.) & 1 & 7623 & $1396.6^{* *}$ \\
Parity $\times$ period & 5 & 7623 & $22.9^{* *}$ \\
Parity $\times$ bST day & 13 & 7623 & $2.1^{*}$ \\
Parity $\times$ milking & 1 & 7623 & $20.7^{* *}$ \\
Period $\times$ bST day & 65 & 7623 & $4.1^{* *}$ \\
Milking $\times$ period & 5 & 7623 & $0.7^{* *}$ \\
Milking $\times$ bST day & 13 & 7623 & $2.6^{* *}$ \\
\hline
\end{tabular}

${ }^{1}$ Numerator.

${ }^{2}$ Denominator.

$* P<0.05,{ }^{* *} P<0.01$

Milking time was shorter for p.m. milkings, when there was less milk than in a.m. milkings. For older and first-lactation cows, there was a decrease in milking time with increasing ACR setting, but less of a decline was observed in the first-lactation cows. The pattern of change in milking time across bST day was similar, except that milking times in the p.m. were lower than those in the a.m. (data not shown).

Body weights were higher in the p.m. compared with a.m. Cows were fed once daily in the morning and did most of their eating and drinking during the day. Older cows gained less weight during the study than firstlactation cows, which were still growing. Because firstlactation cows were growing over the course of the bST cycle, their BW did not decline as much as the cows between $\mathrm{d} 8$ and 14 . Interactions for parity $\times$ period, parity $\times$ milking (a.m. or p.m.), period $\times$ bST day, and

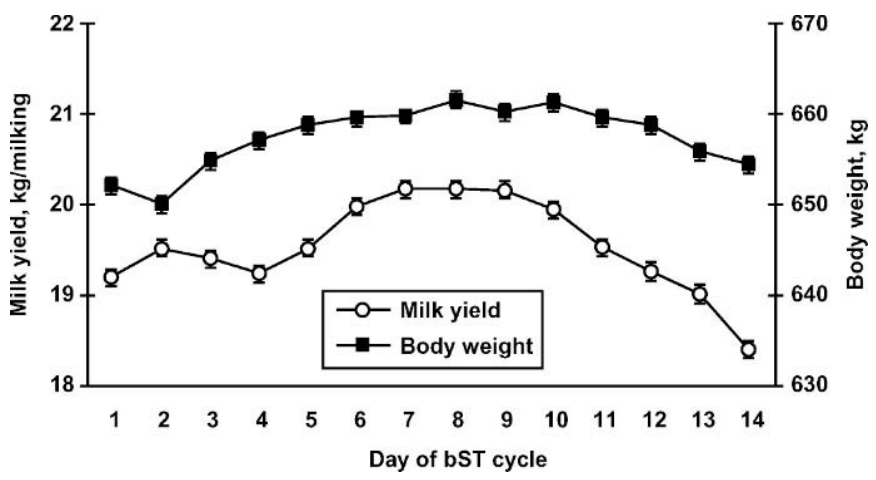

Figure 3. Body weight and milk yield over the 14-d bST cycle. Cows received bST every $14 \mathrm{~d}$ on $\mathrm{d} 1$ of the cycle. Body weight and milk yield were recorded at each milking for a 12 -wk period (6 bST injection cycles). Each data point represents over 480 observations from 59 cows. The effect of day of cycle on milk yield and body weight was significant $(P<0.01)$. Day 1 data reflect the 2 milkings following bST injection, and d 1 milk yields are significantly higher than those seen on d $14(P<0.01)$. milking (a.m. or p.m.) $\times$ bST day each had significant, but subtle, effects on BW, and are of little biological importance (data not shown).

There were 8 cases of clinical mastitis in 7 cows over 4956 cow days, and they were equally distributed among the ACR settings. For the 0.48-, 0.6-, and 0.8$\mathrm{kg} / \mathrm{min}$ settings, there were 3,2 , and 3 cases of clinical mastitis, respectively.

\section{DISCUSSION}

Changing the ACR setting affected both milk yield and milking time. Milk production was similar for the $0.48-$ and $0.6-\mathrm{kg} / \mathrm{min}$ settings, but was reduced by 0.5 $\mathrm{kg} / \mathrm{milking}$ for the $0.8 \mathrm{-kg} / \mathrm{min}$ setting $(P<0.01)$. This differs from results of Stewart et al. (2002) who compared ACR settings of $0.5,0.64,0.73$, and $0.82 \mathrm{~kg} / \mathrm{min}$. They observed no significant effect of ACR setting on milk production, and even a trend for increased milk yield at higher ACR settings. Several issues may account for the discrepancy between our findings and those of Stewart et al. (2002), including differences in milk production, milking frequency, and milking equipment. The cows in the present study averaged 19.6 \pm 5.0 $\mathrm{kg} / \mathrm{milking}$ compared with the $12.85 \pm 1.76 \mathrm{~kg} / \mathrm{milking}$ reported by Stewart et al. (2002). Cows milked 3 times per day generally have less milk per milking, so it is possible that one can use a higher ACR setting for such cows. Both Sagi (1978) and Rasmussen (1993) used lower ACR settings $(0.2$ and $0.4 \mathrm{~kg} / \mathrm{min})$, and neither reported a difference in milk yields between the 2 settings. The present study clearly showed that an ACR setting of $0.6 \mathrm{~kg} / \mathrm{min}$ resulted in faster milking times without sacrificing milk production. Bruckmaier and Hilger (2001) and Caja et al. (2004) have reported that time since last milking and cisternal capacity may affect the increase in intramammary pressure after mammary stimulation. These may play a role in a cow's response to different ACR settings, but were not investigated in the present experiment.

The overall mean milking time of $5.9 \mathrm{~min}$ from the current study is similar to the $5.85 \mathrm{~min} /$ milking reported by Wagner and Ruegg (2002). Milking time in the present experiment decreased as ACR setting increased. Changing the setting from 0.48 to $0.6 \mathrm{~kg} / \mathrm{min}$ resulted in a $6.3 \%(0.4 \mathrm{~min} / \mathrm{cow})$ decrease in milking time. Increasing the setting to $0.8 \mathrm{~kg} / \mathrm{min}$ further decreased milking time by $5.1 \%(0.3 \mathrm{~min} / \mathrm{cow})$. Overall, there was an $11.1 \%$ ( $0.7 \mathrm{~min} / \mathrm{cow}$ per milking) reduction in milking time between the $0.48-$ and $0.8-\mathrm{kg} / \mathrm{min}$ ACR settings. This is consistent with other studies. Sagi (1978) reported a decrease of $0.34 \mathrm{~min} / \mathrm{cow}$ per milking at the $0.4-$ compared with the $0.2-\mathrm{kg} / \mathrm{min}$ setting. Rasmussen (1993) observed a reduction in machine-on time 
with the 0.4-vs. 0.2-kg/min setting. Stewart et al. (2002) reported faster milking times with higher ACR settings although the decrease was shorter $(0.17$ to $0.26 \mathrm{~min} /$ cow per milking) than that observed in the present study or those reported by Sagi (1978) and Rasmussen (1993). It appears that greater improvement in milking time is achieved when moving from a relatively low ACR setting. As the ACR setting nears its optimum, less improvement in milking time would be achieved. Care must be used when comparing milking times across studies because of the differences in milking equipment, milking frequency, milk yields, and final delay settings that may be used.

Parity did not affect milk yield or milking time in the present study. First-lactation cows averaged 24 fewer DIM compared with older cows, which may account for the similar milk production observed. Rasmussen (1993) compared first-lactation animals with multiparous cows in early lactation. For the first 12 wk of lactation, older cows had longer milking times and higher milk production compared with first-lactation animals. Variation in milking time may be more related to individual animal and level of milk production than to age of the animal. In the present study, $76 \%$ of the variation in milking time was due to cow. This is higher than that reported by Touchberry and Markos (1970) and Thomas et al. (1993). However, cows in the present study also produced more milk and may be more representative of today's dairy animals.

Income on dairy farms is affected by the cost of producing milk, the price paid for milk, and the volume of milk produced. Management strategies should balance increasing milk volume and decreasing milking time to maximize net income. Although milking time per cow was reduced with higher ACR settings in the current study, it is not known whether total herd milking time changed. Reid and Stewart (1997) reported 2 case studies where individual cow milking time and total herd milking time were reduced when ACR as well as other milking system settings were changed. Some speculation follows on the practical application of results based upon current findings from a comparison of lowest ( 0.48 $\mathrm{kg}$ of milk/min) to highest ( $0.8 \mathrm{~kg}$ of milk/min) ACR settings. If one assumes that a large modern milking parlor turns over every $15 \mathrm{~min}$ (at 4 turns/h), milks 7 $\mathrm{h}$ per shift, and that an ACR setting of 0.8 will save $0.7 \mathrm{~min} /$ turn when compared with an ACR setting of 0.48 ; then this setting may save $19.6 \mathrm{~min}(=0.7 \mathrm{~min} /$ turn $\times 4$ turns $/ \mathrm{h} \times 7 \mathrm{~h}$ ). This would allow a producer to milk an extra turn of cows at each milking shift with no additional labor. Thus, one may ask whether the potentially lost milk per cow from a higher ACR setting is worth more or less than the additional income that might be generated by one additional turn of cows. The added turn of cows, of course, requires the investment to purchase and maintain those additional cows.

Reduced machine-on time may improve teat-end condition and udder health (Natzke et al., 1982; Mein and Thompson, 1993; Neijenhuis et al., 2000, 2001) thereby providing health and economic benefits that were not measured in the present study.

Others (Maltz, 1997; Østergaard and Gröhn, 1999) have discussed the use of BW and automatic data collection to make dairy management decisions, such as identifying sick cows, making cow grouping decisions, or monitoring cow weight gain or loss. We wanted to examine variation in BW over the bST treatment cycle. The 14-d bST cycle affected both milk yield and BW. Within $2 \mathrm{~d}$ of bST injection, BW and milk yield increased, and peaked by d 8 of the cycle. Thereafter, both BW and milk production decreased. Increases in milk yield in response to bST are well documented (Bauman, 1999). The cyclical production response to sustained release formulations of bST was also observed by Bauman et al. (1989) and Eppard et al. (1991). In the present study, mean daily BW increased by $11 \mathrm{~kg}$ over the same period. This likely reflects increases in feed and water intake (Etherton and Bauman, 1998), total body water (Hanwell and Linzell, 1972), and residual milk which are associated with growth hormone administration and increased milk production. This study documents these changes in BW over the bST cycle, and they are important to report if dairy producers are going to use automated BW data to make dairy farm management decisions. There was an interaction of day of bST cycle $\times$ experimental period $(P<0.01)$, as change in $\mathrm{BW}$ is lower when cows are in earlier stages of lactation (data not shown). Body weight in first-lactation cows did not decline as much from d 8 to 14 of the bST cycle compared with older cows, which reflects that they are still growing.

The present study demonstrates that a comparison of ACR settings is a compromise between milking speed and milk yield. An ACR setting of $0.6 \mathrm{~kg} / \mathrm{min}$ reduced individual cow milking time without affecting production when compared with $0.48 \mathrm{~kg} / \mathrm{min}$. Further testing of ACR settings near $0.6 \mathrm{~kg} / \mathrm{min}$ could identify other ACR settings for further reducing milking time per cow without affecting production. It may be necessary to determine the ACR setting on an individual farm basis because of other variables such as milking frequency, parlor design, degree of milk ejection reflex, vacuum and pulsation settings, and cow grouping. This study also demonstrates that stage of bST cycle has a significant effect on BW in lactating cows. That information may be useful in programs used to make farm management decisions. 


\section{ACKNOWLEDGMENTS}

Financial support for this research was provided by USDA Special Research grant 2000-34281-9764, as well as Hatch funds. The authors wish to thank Nadine Houck and Virginia Ishler for assistance in the conduct of this study.

\section{REFERENCES}

Armstrong, D. V., W. G. Bickert, J. B. Gerrish, and P. W. Spike. 1970. Automatic milking machine removal. J. Dairy Sci. 53:658.(Abstr.)

Bauman, D. E. 1999. Bovine somatotropin and lactation: From basic science to commercial application. Domest. Anim. Endocrinol. 17:101-116.

Bauman, D. E., D. L. Hard, B. A. Crooker, M. S. Partridge, K. Garrick, L. D. Sandles, H. N. Erb, S. E. Franson, G. F. Hartnell, and R. L. Hintz. 1989. Long-term evaluation of a prolonged-release formulation of $\mathrm{n}$-methionyl bovine somatotropin in lactating dairy cows. J. Dairy Sci. 72:642-651.

Bruckmaier, R. M., and M. Hilger. 2001. Milk ejection in dairy cows at different degrees of udder filling. J. Dairy Res. 68:369-376.

Caja, G., M. Ayadi, and C. H. Knight. 2004. Changes in cisternal compartment based on stage of lactation and time since milk ejection in the udder of dairy cows. J. Dairy Sci. 87:2409-2415.

Eppard, P. J., S. Hudson, W. J. Cole, R. L. Hintz, G. F. Hartnell, T. W. Hunter, L. E. Metzger, A. R. Torkelson, B. G. Hammond, R. J. Collier, and G. M. Lanza. 1991. Response of dairy cows to high doses of a sustained-release bovine somatotropin administered during two lactations. 1. Production response. J. Dairy Sci. 74:3807-3821.

Etherton, T. D., and D. E. Bauman. 1998. Biology of somatotropin in growth and lactation of domestic animals. Physiol. Rev. 78:745-761.

Hanwell, A., and J. L. Linzell. 1972. Elevation of the cardiac output in the rat by prolactin and growth hormone. Proc. Soc. Endocrinol. 53:57-58.
Littell, R. C., G. A. Milliken, W. W. Stroup, and R. D. Wolfinger. 1996. SAS System for Mixed Models. SAS Inst. Inc., Cary, NC.

Maltz, E. 1997. The body weight of the dairy cow: III. Use for on-line management of individual cows. Livest. Prod. Sci. 48:187-200.

Mein, G. A., and P. D. Thompson. 1993. Milking the 30,000-pound herd. J. Dairy Sci. 76:3294-3300.

Natzke, R. P., R. W. Everett, and D. R. Bray. 1982. Effect of overmilking on udder health. J. Dairy Sci. 65:117-125.

Neijenhuis, F., H. W. Barkema, H. Hogeveen, and J. P. T. M. Noordhuizen. 2000. Classification and longitudinal examination of callused teat ends in dairy cows. J. Dairy Sci. 83:2795-2804.

Neijenhuis, F., H. W. Barkema, H. Hogeveen, and J. P. T. M. Noordhuizen. 2001. Relationship between teat-end callosity and occurrence of clinical mastitis. J. Dairy Sci. 84:2664-2672.

Østergaard, S., and Y. T. Gröhn. 1999. Effect of diseases on test day milk yield and body weight of dairy cows from Danish research herds. J. Dairy Sci. 82:1188-1201.

Rasmussen, M. D. 1993. Influence of switch level of automatic cluster removers on milking performance and udder health. J. Dairy Res. 60:287-297.

Reid, D. A., and S. Stewart. 1997. The effects on parlor performance by variations of detacher settings. Proc. Natl. Mastitis Counc. 36:101-104.

Sagi, R. 1978. Milk flow rate and end of milking detectors. Proc. Natl Mastitis Counc. 17:328-334.

Stewart, S., S. Godden, P. Rapnicki, D. Reid, A. Johnson, and S. Eicker. 2002. Effects of automatic cluster remover settings on average milking duration, milk flow, and milk yield. J. Dairy Sci. 85:818-823.

Thomas, C. V., M. A. Delorenzo, and D. R. Bray. 1993. Prediction of individual cow milking time for milking parlor simulation models. J. Dairy Sci. 76:2184-2194.

Thompson, P. D. 1981. Milking machines - the past twenty-five years. J. Dairy Sci. 64:1344-1357.

Touchberry, R. W., and H. G. Markos. 1970. Variations in the time required to milk cows. J. Dairy Sci. 53:176-187.

Wagner, A. M., and P. L. Ruegg. 2002. The effect of manual forestripping on milking performance of Holstein dairy cows. J. Dairy Sci. 85:804-809. 